\title{
ASSESSMENT OF AVAILABLE COBALT IN SOME IRAQI CALCAREOUS SOIL USING DIFFERENT EXTRACTION METHODS
}

\author{
(Received:20.10.2010) \\ By \\ N. A. Aziz and O. M. Kadir* \\ Horticulture Department, College of Agriculture, Kirkuk University and \\ * Chemical Technology Department,Technical Institute, Kirkuk, Iraq
}

\begin{abstract}
The present experiments were conducted to study the best technique for extracting available Cobalt from some calcareous virgin soils. The study was carried out on twelve surface samples $(0-30) \mathrm{cm}$ collected from different sites of Kurdistan region in Iraq. The results indicated that the values of chemically extracted available Cobalt varied with the type of the extracting solution and soil . The obtained data showed that the extraction with ( $0.005 \mathrm{M}$ DTPA $\left.+0.01 \mathrm{M} \mathrm{CaCl}_{2}+0.1 \mathrm{M} \mathrm{TEA}\right)$ at $\mathrm{pH} 7.3$ was the best for the determination of available Cobalt in the studied calcareous soils.
\end{abstract}

Key words :calcareous soil, cobalt, extraction

\section{INTRODUCTION}

Scientists differed concerning Cobalt status either as essential mineral for plant growth or not . Legumes and some other plants have a Cobalt requirement independent of nitrogen fixation, although the amount required is small compared to that for the nitrogen-fixation process. (Brady and Ray,2000). Cobalt is essential for the growth of symbiotic microorganisms such as Rhizobia, free living $\mathrm{N}_{2}$-fixing and blue algae and is also important in the synthesis of vitamin $B_{12}$ in ruminant animals. (Havlin et al., 2005). Extraction of available forms of Cobalt for plant nutrition is an important issue to be studied in different types of soil .

In order to assess the proper extraction solution for Cobalt from the soil different extracting solutions and methods have been developed. All procedures are based on the assumption that water soluble, exchangeable , organically bound, occluded in Fe and Mn oxides ,definite compounds and silicates (residual fraction) species of metal exist in soils (Kabata , 2000).

Tessier et al. (1979) were among the first to develop the procedure of sequential extraction to determine the speciation of particular trace metals in soils . Recently three stages of sequential extraction procedures were proposed by the Commission of the Bureau of European Communities References (BCR). This procedure was developed and improved by SMT (Standers Measurements and Testing ) (Formerly BCR) and it will facilitate comparability of data in the European Union . In this technique, metals were divided into three fractions by the application of following chemicals: (1) $\mathrm{CH}_{3} \mathrm{COOH}$,(2) $\mathrm{NH}_{2} \mathrm{OH} . \mathrm{HCl},(3) \mathrm{H}_{2} \mathrm{O}_{2}$ and $\mathrm{CH}_{3} \mathrm{COONH}_{4}$ ( Thomas et al., 1994; Rauret et al., 1999 ) .

The DTPA is designed for the use on higher $\mathrm{pH}$ soils and has been found to be highly correlated with plant availability for some of the nutrient trace elements such as zinc and manganese (Hopkins and Ellsworth, 2005).

In an experiment conducted in Spain the extractable of $\mathrm{Cd}, \mathrm{Ni}, \mathrm{pb}, \mathrm{Cr}$, and $\mathrm{Co}$ from eight contaminated soils were evaluated using ammonium chloride, calcium chloride ,strontium chloride and DTPA extraction .The amounts of metal extracted were related to the total metal contents . Results showed a high availability of metal extraction (Moral et al., 2002) .

The aim of this investigation was to select the proper method for extracting available cobalt from some calcareous soils of Kurdistan region of Iraq.

\section{MATERIALS AND METHODS}

2.1. Sampling : Representative composite soil samples were taken from 12 sites in Kurdistan region of Iraq (Table 1) (Fig1). The collected soil samples were air dried, passed through $2 \mathrm{~mm}$ sieve and subjected to physical and chemical analyses.

\subsection{Physical and chemical analysis}

2.2.1. : The Particle size distribution was 
N. A. Aziz and O.M. Kadir.

Table (1) Location name, location of sites and some field observation

\begin{tabular}{|c|c|c|c|}
\hline Location & Name of locations & Site locations & Descriptions \\
\hline \multirow[t]{3}{*}{ Bazian } & $\begin{array}{l}\text { Gurgaie - shamar } \\
\text { area }\end{array}$ & $\begin{array}{l}\text { About } 3.700 \mathrm{~m} \text { from right side of the } \\
\text { main street.(Bazian). }\end{array}$ & $\begin{array}{c}\text { Natural pastures area for sheep } \\
\text { grazing }\end{array}$ \\
\hline & $\begin{array}{l}\text { Kochak nakhshena } \\
\text { area }\end{array}$ & $\begin{array}{c}\text { About } 10 \mathrm{~km} \text { from right side of Takia } \\
\text { district. }\end{array}$ & $\begin{array}{c}\text { Natural pastures area for sheep } \\
\text { grazing }\end{array}$ \\
\hline & Takia area & $\begin{array}{c}\text { About } 500 \mathrm{~m} \text { from right side of Takia } \\
\text { district }\end{array}$ & $\begin{array}{c}\text { Natural pastures area for sheep } \\
\text { grazing }\end{array}$ \\
\hline \multirow{3}{*}{ Qaradakh } & Bakhan area & $\begin{array}{l}\text { About } 5 \mathrm{~km} \text { from north of Qaradagh } \\
\text { district. }\end{array}$ & $\begin{array}{c}\text { Natural pastures dense area } \\
\text { (Alfalfa cultivated ) for sheep and } \\
\text { goats . }\end{array}$ \\
\hline & Qaraman area & $\begin{array}{c}\text { About } 8 \mathrm{~km} \text { from north of Qaradagh } \\
\text { district }\end{array}$ & $\begin{array}{c}\text { Natural pastures dense area } \\
\text { (Alfalfa cultivated ) for sheep and } \\
\text { goats. }\end{array}$ \\
\hline & Tafan area & $\begin{array}{l}\text { About } 2 \mathrm{~km} \text { from south of Qaradagh } \\
\text { district }\end{array}$ & $\begin{array}{l}\text { Natural pastures dense area for } \\
\text { sheep and goats. }\end{array}$ \\
\hline \multirow{3}{*}{ Arbat } & Bareka area & $\begin{array}{l}\text { About } 1.5 \mathrm{~km} \text { from east of Arbat } \\
\text { district. }\end{array}$ & $\begin{array}{l}\text { Natural pastures dense area for } \\
\text { sheep. }\end{array}$ \\
\hline & Kharaba area & $\begin{array}{l}\text { About } 5 \mathrm{~km} \text { from northeast of Arbat } \\
\text { district }\end{array}$ & $\begin{array}{c}\text { Natural pastures dense area for } \\
\text { sheep. }\end{array}$ \\
\hline & $\begin{array}{l}\text { Darbandn- faqara } \\
\text { area }\end{array}$ & $\begin{array}{l}\text { About } 12 \mathrm{~km} \text { from southeast of Arbat } \\
\text { district }\end{array}$ & $\begin{array}{l}\text { Natural pastures dense area for } \\
\text { sheep and goats grazing. }\end{array}$ \\
\hline \multirow{3}{*}{ Pshdar } & Zoghan area & $\begin{array}{c}\text { About } 700 \mathrm{~m} \text { from east of Sangasar } \\
\text { district. }\end{array}$ & $\begin{array}{l}\text { Natural pastures dense area for } \\
\text { cattle grazing. }\end{array}$ \\
\hline & Sangasar area & $\begin{array}{c}\text { About } 500 \mathrm{~m} \text { from east of Sangasar } \\
\text { district center. }\end{array}$ & $\begin{array}{c}\text { Natural pastures dense area cattle } \\
\text { and sheep }\end{array}$ \\
\hline & Dashtewan area & $\begin{array}{c}\text { About } 1 \mathrm{~km} \text { from east of Sangasar } \\
\text { District . }\end{array}$ & $\begin{array}{l}\text { Natural pastures (clover and alfalfa } \\
\text { ) for cattle grazing }\end{array}$ \\
\hline
\end{tabular}

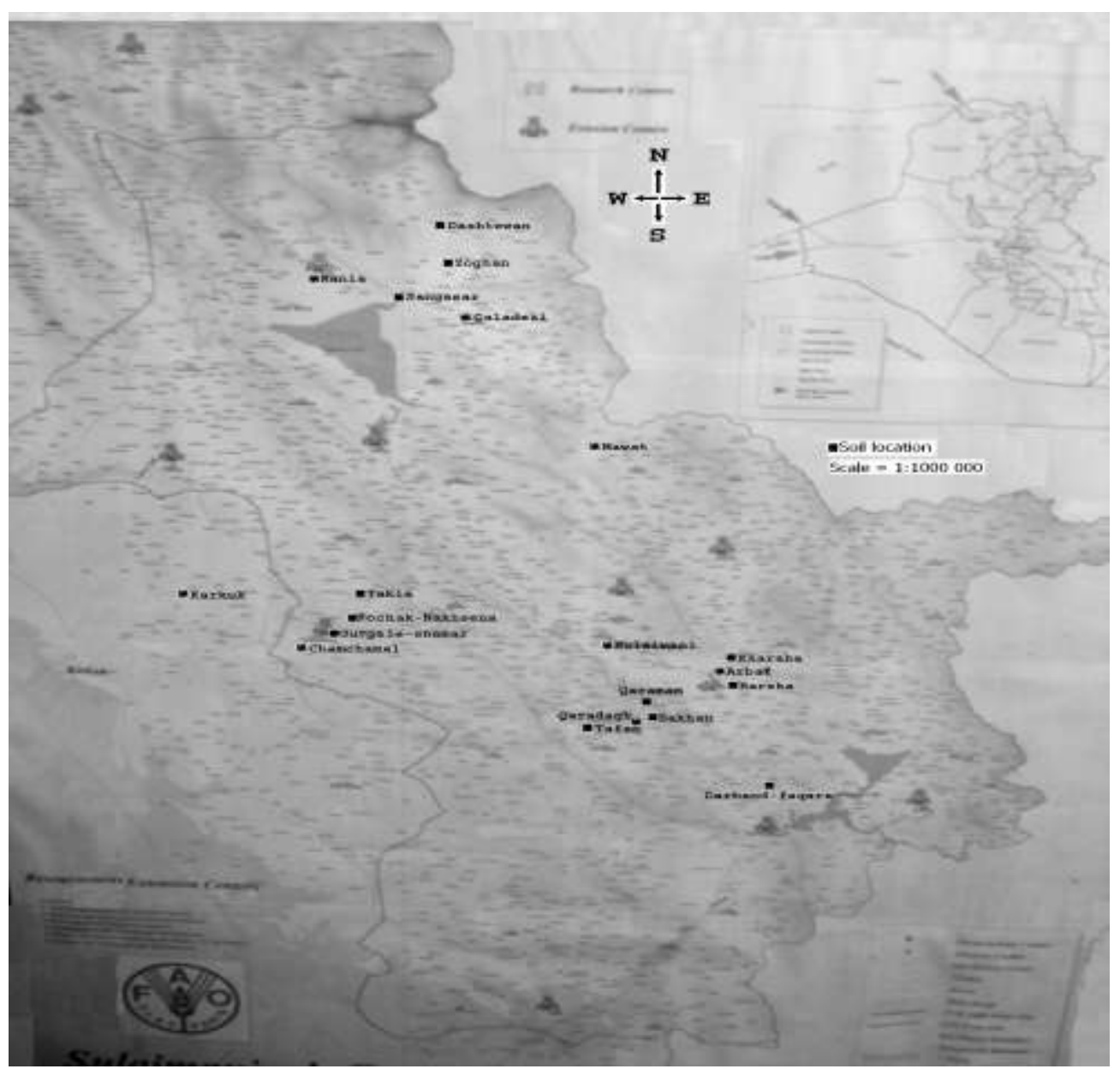

Fig. (1): Location of the studied soil samples 
determined according to the international pipette method as described by Black, (1965).

2.2.2: Field capacity and wilting point were calculated according to empirical equations submitted by ( Karim , 2000 ) .

2.2.3 :Electrical conductivity at $25^{\circ} \mathrm{C}:\left(\mathrm{EC}_{25}\right)$ was measured in soil paste extract as described

by ( Hesse, 1971 ). Soil $\mathrm{pHs}$ and $\mathrm{pH}_{2: 1} 0.0 .1 \mathrm{M}$ $\mathrm{CaCl}_{2}$ of the soils were measured as described in ( Jackson, 1973 ).

2.2.4 : Total carbonate was determined by back titration as described in ( Rowell , 1996 ) and active calcium carbonate was determined using Drouineau procedure as described in( Kozhekov and Yakovleva ,1977 ) .

2.2.5 :Total Cobalt: Total Cobalt was determined by wet digestion method as described in(Jackson,1973).

\subsection{The extraction of Cobalt from these soils} was done as follows:

2.3.1: Water soluble Cobalt extraction :In this method the ratio of 1: 50 soil / distilled water was used as described in (U . S. D .A ,Handbook 60,1969 ).

2.3. 2( 0.005 M DTPA + 0.01 M CaCl $+0.1 \mathrm{M}$ TEA)method :Cobalt was extracted using extracting solution which prepared by $0.005 \mathrm{M}$ DTPA (Diethylene triamine penta acetic acid ) with $0.01 \mathrm{M}$ calcium chloride, and $0.1 \mathrm{M}$ ( TEA ) Triethanolamine, the $\mathrm{pH}$ was adjusted at 7.3 according to ( Lindsay and Norvell, 1978) .

2.3.3 Extraction with NaOAC: Cobalt was extracted with $1 \mathrm{~N} \mathrm{NaOAC}$ at $\mathrm{pH} 8.2$, according to (Jackson, 1973),

\subsubsection{Sequentional extraction method}

A sequential extraction procedure was performed according to the procedure recommended by the Standards Measurements, and Testing programme of the European Union (SM and T-formerly BCR), for the determination of Cobalt in soils. The chosen extraction scheme is an operationally and standardized procedure , in which the reagent used at each stage is intended to release metals associated with particular soil phase such as acid soluble, reducible, oxidisable, and residual , as described by ( Tokalioğlu et al., 2001) .Cobalt determined in the obtained extracts by Atomic Absorption Spectro- photometer ( model Varian Australia Pty Ltd Mulgrave, Victoria ,2005 ).

\subsection{Biological experiment}

Four soil samples ( Takia, Bakhan, Darban faqara , and Dashtewan ) were selected from 12 locations to represent different clay, CEC and
$\mathrm{CaCO}_{3}$ content for the study of Biological experiment . The experiment was performed in a complete randomized design ( CRD ) and in Triplicate during $2006 / 2007$. Each plastic pot was filled with $500 \mathrm{~g}$ gravel, and four $\mathrm{Kg}$ air-dried soil . Alfalfa ( Midcago sativa) was used as indicator plant. Each pot was fertilized with a complete nutrient solution. Five different rates of cobalt ( $0,0.25,0.5,0.75$ and 1$) \mathrm{mg} \mathrm{kg}^{-1}$ were applied to the soils as $\mathrm{Co}\left(\mathrm{NO}_{3}\right)_{2} .6 \mathrm{H}_{2} \mathrm{O}$. Ten seeds were germinated in each pot, and then four plants were left after germination. The water content of the pot was adjusted to $75 \%$ of field capacity throughout the experimental period. Alfalfa shoots were harvested after appearance 10 $\%$ of blooms ( Saeed, 1989).

Harvested shoots were weighed and dried at $65^{\circ} \mathrm{C}$ for $48 \mathrm{hrs}$ to determine the dry matter yields . Dried plant materials were digested using 1:1 ( $\mathrm{H}_{2} \mathrm{SO}_{4}: \mathrm{H}_{2} \mathrm{O}_{2}$ ). ( Schuffeelen and Van Schuwenburg 1961). The Cobalt concentrations in plant digests were determined using Atomic Absorption spectrometer ( model Varian Australia Pty ltd Mulgrave , Victoria , 2005).

\section{RESULTS AND DISCUSSION}

Some physical and chemical properties of the studied soils are shown in (Table 2 ). The results in (Table 3) show the seven extraction methods used for the determination of mobility of Cobalt in soil samples, and their correlations with biological indices .

Natural soils showed that there was positively significant correlation coefficient between Cobalt extracted by DTPA method and Cobalt uptake by the plant $\left(\mathrm{r}=0.955^{*}\right)$. This indicates that the (DTPA $\left.+\mathrm{CaCl}_{2}+\mathrm{TEA}\right)$ method can extract the highest amount of Cobalt in slightly alkaline soils . This might suggest that the chelating agents were more promising for assessing readily available micronutrient cations in soils . This is in agreement with (Abdullah , 2006 ) and (Hopkins and Ellisworth, 2005) .

It was found that there was a negatively significant correlation coefficient among mixed extraction solution $\left(\mathrm{H}_{2} \mathrm{O}_{2}+\mathrm{NH}_{4} \mathrm{OAc}\right)$ with dry matter yield and Cobalt uptake by the plant $(\mathrm{r}$ $\left.=-0.955^{*},-0.95^{*}\right)$ respectively. This indicates that the mixed extraction $\left(\mathrm{H}_{2} \mathrm{O}_{2}+\mathrm{NH}_{4} \mathrm{OAC}\right)$ method can extract the highest amount of oxidizable Cobalt or / and precipitated and it is not a suitable method for the determination of available Cobalt in the studied soils .

In the Cobalt loaded soils, it was found that 
Table (2):Some selected chemical and physical properties of the studied soils;

\begin{tabular}{|c|c|c|c|c|c|c|c|c|c|c|c|c|}
\hline \multirow{2}{*}{$\begin{array}{r}\text { Soil } \\
\text { No }\end{array}$} & \multirow{2}{*}{ Soil location } & \multirow[b]{2}{*}{ Texture } & \multirow[b]{2}{*}{$\begin{array}{c}\text { Saturation } \\
\%\end{array}$} & \multicolumn{2}{|c|}{ pH } & \multicolumn{2}{|c|}{$\mathrm{dS} \cdot \mathrm{m}^{-1}$} & \multicolumn{3}{|c|}{ gm. $\mathrm{kg}^{-1}$} & \multirow[b]{2}{*}{$\begin{array}{l}(\mathrm{A} / \mathrm{T}) \\
\mathrm{x100}\end{array}$} & \multirow[b]{2}{*}{$\begin{array}{c}\text { CEC } \\
\text { Cmol.kg }^{1} \\
\text { soil }\end{array}$} \\
\hline & & & & pHs & $\begin{array}{c}\mathbf{p H}_{1: 2} \\
0.001 \mathrm{M} \\
\mathrm{CaCl}_{2}\end{array}$ & ECs & $\begin{array}{c}\mathrm{EC}_{1: 2} \\
0.001 \mathrm{M} \\
\mathrm{CaCl}_{2}\end{array}$ & O.M & $\begin{array}{c}\text { Total } \\
\text { carbonate }\end{array}$ & $\begin{array}{l}\text { Active } \\
\text { lime }\end{array}$ & & \\
\hline 1 & $\begin{array}{l}\text { Gurgaie- } \\
\text { shamar }\end{array}$ & SCL & 39.53 & 7.57 & 8.38 & 0.43 & 0.17 & 13.22 & 404.3 & 175.5 & 43.40 & 25.11 \\
\hline 2 & $\begin{array}{c}\text { Kochak- } \\
\text { nakhshena }\end{array}$ & SCL & 42.53 & 7.61 & 8.16 & 0.45 & 0.19 & 15.99 & 387.2 & 170.8 & 44.11 & 28.03 \\
\hline 3 & Takia & SCL & 59.11 & 7.28 & 8.12 & 0.44 & 0.18 & 17.04 & 377.9 & 143.3 & 37.92 & 31.21 \\
\hline 4 & Bakhan & SC & 49.88 & 7.30 & 7.41 & 0.41 & 0.20 & 27.12 & 232.7 & 70.9 & 30.46 & 41.12 \\
\hline 5 & Qaraman & SCL & 61.77 & 7.41 & 7.72 & 0.37 & 0.16 & 22.52 & 245.1 & 116.5 & 47.53 & 36.44 \\
\hline 6 & Tafan & SCL & 57.51 & 7.59 & 7.70 & 0.44 & 0.22 & 23.12 & 250.9 & 98.1 & 39.09 & 35.66 \\
\hline 7 & Bareka & SCL & 56.76 & 7.69 & 8.32 & 0.65 & 0.40 & 16.64 & 383.8 & 160.7 & 41.87 & 30.21 \\
\hline 8 & Kharba & SCL & 43.25 & 7.49 & 8.22 & 0.54 & 0.29 & 15.93 & 392.8 & 157.1 & 39.99 & 28.04 \\
\hline 9 & Darban faqara & SCL & 59.86 & 7.73 & 8.31 & 0.34 & 0.14 & 17.43 & 406.2 & 173.8 & 42.78 & 26.22 \\
\hline 10 & Zoghan & SC & 56.26 & 7.03 & 7.32 & 0.54 & 0.16 & 26.03 & 157.7 & 59.9 & 37.98 & 41.10 \\
\hline 11 & Sangasar & SC & 50.23 & 7.09 & 7.39 & 0.61 & 0.28 & 25.11 & 162.2 & 67.5 & 41.61 & 39.98 \\
\hline 12 & Dashtewan & SC & 50.01 & 7.06 & 7.40 & 0.69 & 0.34 & 26.70 & 144.6 & 53.4 & 36.93 & 40.89 \\
\hline
\end{tabular}

$$
\text { SC ------- Silty Clay } \quad \text { SCL -----Silty Clay Loam. } \quad(\mathrm{A} / \mathrm{T}) \times 100=(\text { Active lime / Total carbonate }) \times 100
$$


Table (3) The amount of total and extracted Cobalt with different extracting solution (mgkg $\left.{ }^{-1}\right)$

\begin{tabular}{|c|c|c|c|c|c|c|c|c|c|}
\hline \multirow{2}{*}{$\begin{array}{c}\text { Sample } \\
\text { No. }\end{array}$} & \multirow{2}{*}{$\begin{array}{l}\text { 1:50 Soil } \\
\text { :water }\end{array}$} & \multirow[t]{2}{*}{ NaOAC } & \multirow{2}{*}{$\begin{array}{l}\text { DTPA+CaCl } \\
\text { +TEA }\end{array}$} & \multicolumn{4}{|c|}{ Sequential extraction procedure method } & \multirow{2}{*}{$\begin{array}{c}\text { Pseudo } \\
\text { total }\end{array}$} & \multirow{2}{*}{$\begin{array}{c}\text { Total Co } \\
\text { (Digestion) }\end{array}$} \\
\hline & & & & $\begin{array}{c}\text { Co Extracted with } \\
\mathrm{CH}_{3} \mathrm{COOH}\end{array}$ & $\begin{array}{c}\text { Co Extracted } \\
\text { with } \\
\mathrm{NH}_{3} \mathrm{OH} . \mathrm{HCl}\end{array}$ & $\begin{array}{c}\text { Co Extracted } \\
\text { with } \\
\mathrm{H}_{2} \mathrm{O}_{2+}^{+} \\
\mathrm{CH}_{3} \mathrm{COONH}_{4} \\
\end{array}$ & $\begin{array}{c}\text { Co Extracted } \\
\text { with } \\
3 \mathrm{HCL}+\mathrm{HNO}_{3}\end{array}$ & & \\
\hline 1 & 0.09 & 0.12 & 0.17 & 10.22 & 3.97 & 8.53 & 8.04 & 30.76 & 32.04 \\
\hline 2 & 0.22 & 0.24 & 0.28 & 14.97 & 4.85 & 8.07 & 5.69 & 33.58 & 35.22 \\
\hline 3 & 0.19 & 0.28 & 0.48 & 13.09 & 6.21 & 7.12 & 8.85 & 35.27 & 36.36 \\
\hline 5 & 0.41 & 0.51 & 0.68 & 19.67 & 8.71 & 6.56 & 5.91 & 40.85 & 41.08 \\
\hline 6 & 0.34 & 0.37 & 0.47 & 18.21 & 9.32 & 6.11 & 5.76 & 39.40 & 40.16 \\
\hline 7 & 0.14 & 0.26 & 0.36 & 13.06 & 4.85 & 7.81 & 10.16 & 35.88 & 36.42 \\
\hline 8 & 0.12 & 0.21 & 0.68 & 11.96 & 4.86 & 7.54 & 8.86 & 32.22 & 33.84 \\
\hline 9 & 0.01 & 0.06 & 0.82 & 9.33 & 8.32 & 8.32 & 6.85 & 32.82 & 34.52 \\
\hline 10 & 0.56 & 0.75 & 1.76 & 24.04 & 13.05 & 5.59 & 2.75 & 45.43 & 46.53 \\
\hline 11 & 0.51 & 0.60 & 1.87 & 22.98 & 12.11 & 5.75 & 3.17 & 44.01 & 44.88 \\
\hline
\end{tabular}


Table (4): The correlation coefficient (r) for the relationship between the amounts of Cobalt extracted by different chemical methods and biological indices.

\begin{tabular}{|c|c|c|c|c|c|c|c|c|c|c|c|c|c|c|c|}
\hline \multirow{3}{*}{$\begin{array}{c}\text { Chemical extraction } \\
\text { methods } \\
\left(\text { mg.kg }^{-1}\right)\end{array}$} & \multicolumn{3}{|c|}{$\begin{array}{l}\text { Non-application of Cobalt in } \\
\text { pots }\end{array}$} & \multicolumn{12}{|c|}{ Application of Co fertilizer } \\
\hline & \multirow{2}{*}{$\begin{array}{c}\begin{array}{c}\text { gm. } \\
\text { pot }^{-1}\end{array} \\
\begin{array}{c}\text { Dry } \\
\text { matter }\end{array}\end{array}$} & \multicolumn{2}{|c|}{$\mu g C o . g m^{1}$ plant } & \multicolumn{4}{|c|}{ Dry matter yield gm. pot ${ }^{-1}$} & \multicolumn{4}{|c|}{$\begin{array}{l}\text { Co concentration in plant } \\
\mu \mathrm{gCo} \cdot \mathrm{gm}^{-1} \text { plant }\end{array}$} & \multicolumn{4}{|c|}{$\begin{array}{l}\text { Uptake of Co by plant Uptake } \\
\mu \mathrm{gCo} \mathrm{gm}^{-1} \text { plant }\end{array}$} \\
\hline & & $\begin{array}{l}\text { Co Conc. } \\
\text { in plant }\end{array}$ & $\begin{array}{l}\text { Uptake } \\
\text { of Co by } \\
\text { plant }\end{array}$ & 0.25 & 0.5 & 0.75 & 1 & 0.25 & 0.5 & 0.75 & 1 & 0.25 & 0.5 & 0.75 & 1 \\
\hline Water soluble & N.S & N.S & N.S & 0.96* & N.S & $0.95 *$ & N.S & 0.98* & 0.98* & $0.99 * *$ & $0.99 * *$ & $0.95 *$ & N.S & N.S & N.S \\
\hline NaOAC & N.S & N.S & N.S & N.S & N.S & N.S & N.S & $0.96 *$ & $0.93^{*}$ & $0.98 *$ & $0.99 * *$ & N.S & N.S & N.S & N.S \\
\hline DTPA & N.S & N.S & $0.955 *$ & N.S & N.S & N.S & N.S & N.S & N.S & N.S & N.S & N.S & $0.95 *$ & N.S & N.S \\
\hline $\mathrm{CH}_{3} \mathrm{COOH}$ & N.S & N.S & N.S & $0.96 *$ & $0.95 *$ & $0.95 *$ & $0.94 *$ & $0.96 *$ & $0.97 *$ & $0.99 * *$ & $0.99 * *$ & N.S & N.S & N.S & N.S \\
\hline $\mathrm{NH}_{2} \mathrm{OH} . \mathrm{HCl}$ & N.S & N.S & N.S & N.S & N.S & N.S & N.S & N.S & N.S & N.S & N.S & N.S & N.S & N.S & N.S \\
\hline $\mathrm{H}_{2} \mathrm{O}_{2}+\mathrm{H}_{3} \mathrm{COONH}_{4}$ & $-0.95^{*}$ & N.S & $-0.95^{*}$ & $-0.97 *$ & $-0.95^{*}$ & $-0.97 *$ & $-0.96 *$ & $-0.96 *$ & $-0.99 * *$ & $-0.97 *$ & $-0.96 *$ & $-0.96 *$ & $-0.95^{*}$ & $-0.95 *$ & $-0.95 *$ \\
\hline Aqua regia $\left({ }_{3} \mathrm{HCl}+{ }_{1} \mathrm{HNO}_{3}\right)$ & N.S & N.S & N.S & N.S & N.S & N.S & N.S & N.S & N.S & N.S & N.S & N.S & N.S & N.S & N.S \\
\hline
\end{tabular}

N.S Correlation is not significant.

* Correlation is significant at 0.05 levels.

** Correlation is significant at 0.01 level 
soluble Cobalt was significantly correlated to dry matter yield $\left(r=0.96^{*}, 0.95^{*}\right)$ for the levels the plant $(\mathrm{r}=0.98 *, 0.98 *, 0.99 * *, 0.99 * *)$ at levels of $(0.25,0.5,0.75,1) \mu \mathrm{g}$ Co .gm, respectively and Cobalt uptake $(\mathrm{r}=0.95 *)$ at a level of $0.25 \mu \mathrm{g} \mathrm{Co} \mathrm{gm}^{-1}$. This indicates that the water soluble method has the ability to extract soluble Cobalt from these soils and a good indication for intensity factor.

A positive significant correlation was found between ammonium acetate ( $\mathrm{NaOAc})$ and acetic acid $\left(\mathrm{CH}_{3} \mathrm{COOH}\right)$ extracting solution, and Cobalt concentration in plant $\left(\mathrm{r}=0.96^{*}, 0.93 *\right.$ $\left., 0.98^{*}, 0.99^{* *}\right)$, and $\left(\mathrm{r}=0.96^{*}, 0.97^{*}, 0.99^{*}\right.$, $0.99 *)$ at a levels of $(0.25,0.5,0.75,1) \mu \mathrm{g}$ Co.gm ${ }^{-1}$ respectively (Table 4).

Also, we found that there were positive significant correlation coefficients between acetic acid $\mathrm{CH}_{3} \mathrm{COOH}$ method and dry matter yield $\left(r=0.96 *, 0.95^{*}, 0.95^{*}, 0.94 *\right)$ at a level of added Cobalt $(0.25,0.5,0.75,1) \mu \mathrm{g} . \mathrm{gm}^{-1}$, respectively .

This indicates that $\mathrm{NaOAC}$ and acetic acid methods had the ability to extract exchangeable Cobalt from these soils but the NaOAC method extracted the lowest exchangeable Cobalt, while the $\mathrm{CH}_{3} \mathrm{COOH}$ method extracted the highest amounts of exchangeable Cobalt. This might be due to that the acetic acid $\mathrm{CH}_{3} \mathrm{COOH}$ method is acidic extraction which reduce the $\mathrm{pH}$. Hydrogen ions can displace metallic cations from the colloidal complex at low $\mathrm{pH}$.Whereas NaOAC reduce acidity and increase the soil $\mathrm{pH}$. Consequently, $\mathrm{Na}$ can not easily displace $\mathrm{Ca}, \mathrm{Mg}$, and $\mathrm{K}$ from soil colloidal surfaces. This is in agreement with ( Kabata ,2000) .

It was found that there were several significant correlations among DTPA and Cobalt uptake by plant $\left(r=0.95^{*}\right)$ at a levels of $(0.50)$ $\mu \mathrm{g} . \mathrm{gm}^{-1}$ added Cobalt .This indicates that DTPA can extract available Cobalt at level ( 0.50$) \mu \mathrm{g} . \mathrm{g}$ $\mathrm{m}^{-1}$.On the other hand negative significant correlation coefficients were obtained among ( $\mathrm{H}_{2} \mathrm{O}_{2}+\mathrm{NH}_{4} \mathrm{OAC}$ ) method with dry matter yield $\left(\mathrm{r}=-0.97^{*},-0.95^{*},-0.97^{*}, \quad-0.96^{*}\right)$, Cobalt concentration in plant $\left(\mathrm{r}=-0.96^{*},-0.99^{*}\right.$, $\left.0.97^{*},-0.96^{*}\right)$ and Cobalt uptake by plant $(\mathrm{r}=$ $\left.-0.96^{*},-0.95^{*},-0.95^{*},-0.95^{*}\right)$ at a levels of ( $0.25,0.50,0.75,1) \mu \mathrm{g} . \mathrm{gm}^{-1}$ added Cobalt , respectively. This indicates that mixed extracting solution $\left(\mathrm{H}_{2} \mathrm{O}_{2}+\mathrm{NH}_{4} \mathrm{OAC}\right)$ can extract high amounts of non-available Cobalt. The efficiency of the various extracting solutions for the determination available Co content could be arranged : ( 8.8 mol. $\mathrm{L}^{-1} \mathrm{H}_{2} \mathrm{O}_{2}+1.0$ mol. $\mathrm{L}^{-1} \mathrm{NH}_{4}$
$\mathrm{OAC}$ at $\mathrm{pH} 2$ ) $<1: 50$ water soluble $<1 \mathrm{~N}$ $\mathrm{NaOAC}$ at $\mathrm{pH} 8.2<(0.005 \mathrm{M}$ DTPA $+0.01 \mathrm{M}$ $\mathrm{CaCl}_{2}+0.1 \mathrm{M}$ TEA $)$ at $\mathrm{pH} 7.3<(0.11 \mathrm{~mol}$. $\mathrm{L}$ $\left.{ }^{1} \mathrm{CH}_{3} \mathrm{COOH}\right)$ at $\mathrm{pH} 2.85$.

The abovementioned results indicated that the ( 0. $005 \mathrm{M} \mathrm{DTPA}+0.01 \mathrm{M} \mathrm{CaCl}_{2}+0.1 \mathrm{M}$ TEA ) at $\mathrm{pH} 7.3$ method was the best extraction method for the determination of available Cobalt in slightly alkaline and calcareous soils because it has been found to be significant correlated with dry matter yield ,cobalt concentration in plant and cobalt uptake by plant at different levels and NH4OAC is not adapted or not successful method to evaluate availability of cobalt in studied soils due to negative correlations.

These finding could help to select the best extraction method for available Cobalt from calcareous soils .

\section{REFERENCES}

Abdullah, S.M.S.( 2006 ) . Availability indices and physical-chemical behavior of $\mathrm{Fe}$ in calcareous soils .A thesis of Master in Science, Agriculture, College University of Sulaimania .

Black, C.A . ( 1965 ) . Methods of Soil Analyses .Agron. Mono .9.Part 1,2 Amer. Soc. Agron . Manison,Wisconsin .

Brady, N. C. , and Ray R . W .(2000). The Elements of the Nature and Properties of Soils. Upper Saddle Rover, New Jersey: Prentice .

Havlin J.L. , Beaton J.D ., Tidal, S.L . , and Nelson W.L .) ( 2005 ). Soil Fertility and Fertilizers . 7th Ed . An Introduction to Nutrient Management . Prentice -Hall, Inc ., N . J .290-291 .

Hesse , P.R. (1971 ). A Text Book of Soil Chemical Analysis. William Clowes and Sons Limited, London, Beccles and Colchester. Chemical Publishing Co.Inc., New York .

Hopkins , H . , and Ellsworth, J. W. ( 2005 ). Trace metal toxicity from manure in Idaho: Emphases on copper. Proceedings of the Idaho Alfalfa and Forage Conference . University of Idaho Extension .

Jackson, M.L.( 1973). Soil Chemical Analysis . Prentice - Hall. Inc. Englewood . Cliffs, N.J .

Kabata - Pendias , A., and Pendias H. ( 2000 ) . Trace Elements in Soil and Plants , $3^{r d}$ Ed. , Boca Raton London, FL , CRC press

Karim , T.H . (2000) . Models to predict water retention of Iraq Soils. Indian and Plants , $3^{\text {rd }}$ Ed , Boca Raton London , FL , CRC press Journal of Soil Sci .No. 47: 19 -23.

Kozhekov D. K and Yakovleva (1977). Determination of carbonates and carbonate 
minerals in soils . Soviet Sci . J .No. $10: 620$ 626.

Lindsay W. L ., and Norvell W.A . ( 1978 ). Development of DTPA micronutrient soil test for $\mathrm{Zn}, \mathrm{Fe}, \mathrm{Mn}$, and Co . Soil . Soc . Amer . No . 42 :421-428.

Moral R ., Robert J ., Gilkes , Joaquin , Moreno and Caselles (2002). A comparison of extractants for heavy metals in contaminated soils from Spain.: Tayor \& Fracis .Vol. 15.No. $18: 2781-2791$.

Rauret, G., Lopezsanchez, J.F., Sahuquillo, A., Rubio, R., Davidson,C., Urea and Quevauviller, P.( 1999). Improvement of the BCR three step sequential extraction J. Envir. Monitor. No. 1(1), 57-61.

Rowell, D .L . (1996 ). Soil science . Methods and Applications. University of Reading .UK.

Saeed ,K.S . ( 1989 ). Effect of Rhizobium, N and Mo on productivity and quality of annual medic .A thesis of Master of Science Agriculture College, Baghdad University .
Schuffeelen, A .C .A ., and Van Schuwenburg, J.C.H . ( 1961 ) . For soil and plant analysis used by small laboratories . Neth. Jour.Agri. Aci . No. 9 :2-16.

Tessier, A ., Campbell, P .C. S ., and Bisson , M . (1979). Sequential extraction procedure for the speciation of particulate trace metals . Anal .Chem . No. 51: 844-851.

Thomas, R.P., Ure, A.M., Davidson, C.M., Littlejohn, D., Rauret, G., and Lopezsanchez, J.F. (1994) . 3 -Stage sequential extraction procedure for the determination of metals in river sediments. Analyt. Chim. Acta. Vol.3 No. 286 : 423-429.

Tokalioğlu S ., Kartal S and Birol G .2001 ).Application of a Three - stage Sequential Extraction Procedure for the determination of Extractable Metal Contents in Highway Soils . Turk, J Chem . (C) TUBITAK. No. 27: 333 346 .

U.S.D.A. Salinity Laboratory Staff, (1969). Diagnosis and Improvement of saline and alkali soil. Hand Book No. 60:16-18

\footnotetext{
تقدير الكويلت الجاهز في بعض الترب الكلسية في العراق بأستخدام طرق ومحاليل إستخلاص مختلفة 